\title{
PENELITIAN
}

\section{PERSEPSI PERAWAT DAN KELUARGA PASIEN TENTANG PENGETAHUAN YANG DIPERLUKAN UNTUK MERAWAT ODHA DI RUMAH SAKIT DAN DI RUMAH}

\author{
Agung Waluyo *, Lestari Sukmarini **, Ns. Rosakawati ***
}

\begin{abstract}
Abstrak
Tujuan penelitian fenomenologi ini adalah mengidentifikasi persepsi perawat dan keluarga pasien HIV/AIDS tentang pengetahuan yang diperlukan perawat dan keluarga yang merawat untuk merawat pasien HIV/AIDS di rumah sakit dan di rumah. Sejumlah 5 perawat \& 5 keluarga pasien berpartisipasi dalam penelitian ini. Dari hasil analisis didapatkan 6 hal yang harus diketahui perawat. Persepsi perawat tentang pengetahuan dan keterampilan yang harus dimiliki perawat saat merawat pasien HIV/AIDS adalah: (1) pengetahuan dan keterampilan tentang konseling, (2) ARV \& efek sampingnya, (3) Universal Precaution, (4) symptom management, (5) dukungan mental, dan (6) penanganan jika terpapar HIV. Sedangkan dari keluarga ada 4 hal yang harus diketahui oleh keluarga saat mereka merawat pasien di rumah, yaitu: (1) pengetahuan tentang HIV/AIDS \& cara penularannya, (2) pengetahuan tentang tanda \& gejala HIV/AIDS, (3) pengetahuan dan keterampilan tentang pencegahan penularan (Universal Precaution) dan (4) symptom management. Rekomendasi penelitian ini adalah perlu ada penelitian lanjut pada jumlah responden yang lebih luas. Hasil penelitian ini dapat digunakan untuk meningkatkan efektifitas asuhan keperawatan pada pasien HIV/AIDS dan juga kualitas hidup pasien saat mereka di rumah
\end{abstract}

Kata kunci: HIV/AIDS, keluarga, keterampilan, pengetahuan, perawat

\begin{abstract}
The purpose of this phenomenology study was to identify the nurse's and relative's perception on knowledge and skill needed by the nurses \& relatives in caring patient in the hospital and in their house. Ten respondents (5 nurses and 5 relatives of the patients) participated the study. The findings identified knowledge \& skill needed by nurses are: (1) knowledge \& skill on counseling, (2) Anti Retro Viral therapy \& its side effect, (3) universal precaution, (4) symptom management, (5) mental support, and (6) treatment standard on occupational exposure to HIV. The findings from the relative's are: (1) knowledge on HIV/AIDS and how it spreads (2) knowledge on signs \& symptoms of HIVIAIDS, (3) knowledge \& skill on universal precaution and (4) symptom management. Some recommendations of the study were proposed that this study should be continued to have some other respondents. The result of these studies could be beneficial to improve the nursing care to the HIV/AIDS patient and their quality of life during AIDS stage, and it could be beneficial to the improvement the effectively of the nursing care of patient with HIV/AIDS.
\end{abstract}

Key words: : HIV/AIDS, knowledge, nurse, relatives, skill

\section{LATAR BELAKANG}

Jumlah pasien HIV di Indonesia terus bertambah. Total jumlah pasien HIV/AIDS yang dilaporkan sebanyak 4.159 orang (Pelita Ilmu, 2003). Namun dari Badan Narkotika Nasional memperkirakan pada 2002 ada 110.000 orang mengidap HIV positif, dan yang lebih mengejutkan lagi mereka memperkirakan pada 2005 terdapat 570.000 pengguna narkoba suntik di mana $80 \%$ dari mereka diperkirakan HIV positif. Hal ini memperjelas perkiraan-perkiraan yang telah dilansir pada 2 tahun belakangan ini bahwa penderita HIV karena jarum suntik hampir menduduki posisi teratas (DepKes, 2005).

Peningkatan jumlah penderita HIV /AIDS saat ini sudah selayaknya diikuti dengan peningkatan pengetahuan perawat dan keluarga yang merawat pasien HIV/AIDS. Untuk perawat, tidak hanya pengetahuan saja yang penting ditingkatkan namun juga keterampilan yang mereka miliki untuk merawat pasien dengan HIV/AIDS baik di fasilitas kesehatan maupun di masyarakat (WHO, 2004). 
Penelitian yang telah dilakukan oleh Culbert \& Waluyo (2003) pada sekelompok mahasiswa keperawatan terlihat bahwa sebagian dari mereka memiliki pengetahuan yang masih kurang tentang perawatan pasien HIV/AIDS. Hal ini dapat disebabkan persepsi yang berbeda-beda di antara perawat tentang perawatan yang dibutuhkan oleh pasien HIV/AIDS dan keluarga yang merawat pasien HIV/AIDS di rumah. Untuk itu maka perlu dikaji lebih lanjut persepsi perawat dan keluarga pasien HIV/AIDS tentang pengetahuan yang diperlukan perawat atau keluarga yang merawat untuk merawat pasien HIV/AIDS di rumah sakit dan di rumah.

\section{BAHAN \& CARA KERJA}

Tujuan penelitian ini adalah mengidentifikasi persepsi perawat dan keluarga pasien HIV/AIDS tentang pengetahuan yang diperlukan perawat atau keluarga yang merawat untuk merawat pasien HIV/ AIDS di rumah sakit dan di rumah. Pendekatan fenomenologi pada penelitian ini memungkinkan peneliti melakukan eksplorasi secara mendalam pada perawat dan keluarga pasien yang merawat pasien HIV/AIDS, serta bagaimana mereka menyampaikan persepsi dan pengalamannya tentang perawatan pasien HIV/AIDS (Stephenson \& Corben, 1997).

Penelitian ini dilakukan pada lima perawat yang bekerja di ruangan yang merawat pasien HIV/AIDS di dua rumah sakit pemerintah di Jakarta dan lima keluarga yang menunggu atau bertugas membantu merawat selama pasien dirawat. Sampel yang digunakan diambil secara purposif yaitu perawat yang bertugas merawat pasien HIV/AIDS dan keluarga dari pasien yang telah dinyatakan positif HIV dari pemeriksaan ELISA. Kriteria sampel adalah dapat berbahasa Indonesia, dan sampel keluarga merupakan anggota keluarga pasien yang terdekat (Ayah, Ibu, anak maupun saudara-saudara kandung pasien) yang secara aktif menjadi bagian dari sistem pendukung pasien. Wawancara indepth interview dengan menggunakan pedoman wawancara sambil mengobservasi respon verbal dan non verbal responden. Wawancara dan observasi ini dilakukan dalam waktu 30 - 45 menit selama 14 minggu.

\section{HASIL}

Pendidikan perawat yang menjadi responden adalah Akademi (D3) Keperawatan dan berjenis kelamin wanita dengan lama kerja 2-3 tahun dan usia 24-27 tahun. Untuk responden keluarga pasien adalah kakak kandung (berjenis kelamin pria dan wanita) dan orangtua (ibu) dari klien HIV/AIDS dengan usia 45 55 tahun dengan latar belakang pendidikan sekolah menengah atas sampai perguruan tinggi. Tema-tema yang didapat dari proses analisis adalah sebagai berikut:

\section{PENGETAHUAN DAN KETERAMPILAN YANG DIBUTUHKAN PERAWAT}

Persepsi perawat tentang pengetahuan dan keterampilan yang harus dimiliki perawat saat merawat pasien HIV/AIDS adalah pengetahuan dan keterampilan tentang konseling, ARV dan efek sampingnya, universal precaution, symptom management, dukungan mental, dan penanganan jika terpapar HIV.

\section{Pengetahuan dan keterampilan tentang konseling}

Kemampuan memberikan konseling menjadi sangat penting dimiliki perawat dalam pemberian asuhan keperawatan seperti yang disampaikan responden di bawah ini:

\footnotetext{
"Saya kadang mengalami kesulitan saat memberikan asuhan keperawatan terutama untuk klien yang tidak kooperatif, sering kali saya merasa mereka belum "trust" (percaya). Mungkin kalau kita dibekali kemampuan konseling hal tersebut dapat diminimalkan" (P1)

"Mmm.... Kemampuan konseling penting buat saya atau teman2 perawat yang lain. Karena kalau kita tidak bisa memberikan konseling, rasanya agak sulit bagi kita untuk bisa membantu menyelesaikan masalah pasien." (P3)
}

\section{Pengetahuan dan keterampilan tentang ARV \& efek sampingnya}

Pengetahuan dan keterampilan dalam melakukan intervensi kolaboratif pemberian pengobatan anti retroviral (ARV) juga menjadi hal yang disampaikan oleh beberapa responden. Responden ingin mengetahui lebih banyak dan bertanggung jawab terhadap apa yang dilakukannya, lebih dari sekedar memberikan obat saja. 
"Keterampilan yang penting diketahui perawat adalah tentang obat-obatan HIV. Perawat harus tahu fungsi dari obat-obatan HIV, kapan diberikan, apa efek sampingnya. Kadang kan kita kasih obat aja, tidak semua perawat mengerti. Contoh ada pasien anemia, dia tetap diberi Duviral, harusnya perawat tahu dong pasien tidak boleh dapat, tidak hanya dokternya aja. Contoh lainnya kapan pasien diberi OAT, kapan pasien bisa memulai ARV pada nilai SGOT/SGPT berapa..”(P2)

"Seperti kita memberi obat-obatan, kita sudah memberikannya sesuai jadwal. Tapi kadang2 apabila pada kondisi tertentu misal pada pemberian obat jam 14.00 dan 21.00 kadang lupa, saya tidak tahu apa yang mungkin terjadi pada pasien, apakah mereka akan mengalami resisten akibat yang telah saya lakukan tersebut" (P5).

Respon P2 menunjukkan bahwa perawat harus mengetahui reaksi obat dalam tubuh pasien, bagaimana cara kerjanya, apa efek sampingnya. Sedangkan responden P5 berpersepsi lebih pada bagaimana perawat dapat mencegah kemungkinan terjadinya resistensi.

\section{Pengetahuan dan keterampilan tentang Universal Precaution}

Persepsi yang muncul tentang universal precation ini cukup beragam, seperti mengkritisi sebagian perawat tentang kualitas asuhan yang diberikan dan penanganan cairan tubuh pasien.

"Aku rasa keterampilannya kurang, apa lagi di RS ini, kebanyakan perawat di sini hanya sekedar merawat2 aja tanpa memiliki keterampilan khusus saat menangani cairan pasien, bahkan ada perawat yang berusaha menghindar untuk merawat pasien HIV/AIDS karena takut tertular....." (P1)

"Seperti di ruangan hanya ketua tim atau tim tertentu saja yang tahu cara penanganan atau pencucian alat bekas pasien HIV. Saya melihat tidak adanya standar operasional prosedur untuk itu. Misal pasien muntah di lantai cleaning servicenya tidak tahu caranya dan tidak diajarkan cara membersihkannya menggunakan cairan disinfektan tertentu." (P2)

Sebagian responden lain (P4) berpersepsi lain yaitu dengan menghubungkan universal precaution dengan kasus lain seperti TBC paru.

"Pertama yang perlu diketahui oleh perawat adalah proteksi, karena berdasarkan dari pengalaman saya mereka pasien pasien HIV umumnya/kebanyakan sudah TB. Sementara kita kan harus berkomunikasi, selama 8 jam satu shift itu kita bisa bolak balik ke pasien apalagi dalam satu ruangan itu memang dikhususkan untuk pasien2 yang seperti itu. Sehingga proteksi diri itu penting diketahui oleh perawat". (P4)

\section{Pengetahuan dan keterampilan tentang symptom management}

Tidak banyak responden yang memiliki persepsi bahwa pengetahuan dan keterampilan pada symptom management sebagai hal yang mereka butuhkan, tapi setidaknya responden P3 menyatakan bahwa perawat juga harus mampu menangani keluhan pasien, tanpa harus selalu menunggu instruksi dokter. Responden ini juga menyampaikan kebutuhan pengetahuan dan keterampilan symptom management terkini yang dapat membantu mereka mengatasi keluhannya

"Kadang pasien HIV itu manja. Maksudnya jika tidak ada jadwal minum obat, terus pasiennya mengeluh sakit kepala, kita mungkin harusnya upayakan dia mendapatkan tindakan keperawatan dulu. Biasanya kan dengan relaksasi dan nafas dalam itu bisa menolong, tapi saya kadang juga agak ragu apakah untuk mengurangi keluhan sakit kepala hanya itu tindakannya". (P3)

“....apabila pasiennya febris-febris gitu (peningkatan suhu tubuh) mestinya sebelum tindakan yang medis-medis kita coba dulu keperawatannya. Misalnya minum banyak, kompres air hangat, kebanyakan mereka maunya obat langsung". Mereka biasanya bilang "Udah gak mempan nih, obat aja deh, jadi sebenarnya kita di ruangan butuh tindakan keperawatan terkini untuk febris".

"Kadang-kadang kita berfikir bagaimana kita bisa melakukan asuhan keperawatan yang tepat, terutama dengan gejala-gejala yang muncul" (P3).

\section{Pengetahuan dan keterampilan tentang dukungan mental}

Responden yang mempersepsikan bahwa pengetahuan dan keterampilan tentang pemberian dukungan mental dibutuhkan perawat dalam memberikan asuhan keperawatan pada klien HIV/ AIDS tidak banyak. Namun responden mengaitkan kemampuan pemberian dukungan mental pada kemampuan perawat dalam mengajarkan anggota keluarga agar mereka dapat selalu mendukung pasien.

"Yang ketiga yang harus diketahui adalah biasanya pasien2 yang seperti itu kan keluarganya perlu mengetahui bagaimana cara mensupport pasiennya. Jika kita tidak tahu bagaimana memberikan dukungan mental, bagaimana keluarganya?” (P1) 


\section{Pengetahuan dan keterampilan tentang penanganan jika terpapar HIV}

Sama seperti pengetahuan dan keterampilan dukungan mental dan symptom management, responden yang mempersepsikan kebutuhan ini tidak banyak, seperti yang disampaikan oleh P4:

"Mungkin yang menjadi pikiran saya adalah bagaimana kalau kita ketusuk jarum pasien HIV/AIDS. Pertama kita mungkin akan merasa stress yang paling hebat, tapi saat kita terkena suntikan tersebut, apa yang harus kita lakukan? Apakah kita dapat langsung konsultasi dengan timnya, langsung cek anti HIV, trus apakah kita perlu langsung makan ARV?" (P4)

\section{PENGETAHUAN DAN KETERAMPILAN YANG DIBUTUHKAN KELUARGA PASIEN SAAT MERAWAT PASIEN DI RUMAH}

\section{Pengetahuan tentang HIV/AIDS dan cara penularannya}

Tidak seperti responden perawat, respondenresponden keluarga pasien menyampaikan hal yang lebih dasar seperti pengetahuan tentang HIV/AIDS dan cara penularannya. Seperti yang disampaikan beberapa responden keluarga pasien:

\footnotetext{
"Ya...aku....mungkin merasa kurang pengetahuan, HIV itu apa, bagaimana dapatnya, penularannya yang lebih detail itu bagaimana......dan informasi 2 yang lebih luas lagi tentang perkembangan HIV aku belum tahu sedetail itu.........." (K1)
}

Terlihat bahwa responden $\mathrm{K} 1$ ingin tahu lebih banyak tentang apa itu HIV/AIDS dan proses penularannya. Sedikit berbeda dengan responden K1, responden K2 menggarisbawahi adanya kemungkinan penularan di dalam hubungan suami-istri apabila salah satu dari mereka mengidap HIV.

“.....seperti HIV memang menular lewat hubungan seks, tapi hubungan seks yang seperti apa? Apa kalau ada suami positif trus hubungan suami istri, si istri bisa berisiko....... Ih serem....." (K2)

Sedangkan pada responden K4 menghubungkan pengetahuan tentang HIV dan penularannya dengan kecenderungan anggota keluarga lain untuk menolak merawat pasien terutama apabila pasien sudah boleh dipulangkan. Hal itu semua dimungkinkan akibat ketidaktahuannya pada cara penularan HIV/AIDS.

\begin{abstract}
"Saya masih bingung HIV kan berbahaya banget kan...... apa bisa menular kalau kita kontak sama pasien? Saudarasaudara saya yang lain bukan gak mau ngerawat tapi mereka masih takut (bingung red.). Apa lagi kalau memang udah boleh pulang (pasiennya red.) ." (K4).
\end{abstract}

\section{Pengetahuan tentang tanda dan gejala HIV/ AIDS}

Hal lain yang dipersepsikan responden keluarga sebagai pengetahuan yang dibutuhkan oleh mereka adalah tanda dan gejala HIV/AIDS. Pendapat yang muncul tentang tanda dan gejala HIV/AIDS ini cukup beragam, seperti yang disampaikan oleh responden $\mathrm{K} 2$, K3 dan K5.

"Menurut saya....mungkin pengetahuan tentang tandatanda misalnya seseorang pertama kali terkena HIV. Mungkin itu penting sekali diketahui oleh kita apalagi kalau sudah di rumah, jadi kita enggak nebak-nebak misalnya kita sendiri tertular apa enggak.

Responden K2 menyampaikan kebutuhan akan pengetahuan dasar tentang tanda dan gejala HIV/ AIDS, dan K3 lebih pada tanda dan gejala sesuai dengan tahapan HIV positif sampai kondisi AIDS. Sedangkan K5 menyampaikan bahwa pengetahuan tentang tanda \& gejala menjadi penting terutama untuk membekali dirinya akan informasi tentang tanda apabila seseorang telah tertular HIV.

\footnotetext{
"Kita bisa memperkirakan jika seseorang mulai terinfeksi, atau seseorang yang sudah parah terkena AIDS" (K3)

"Bagaimana kita bisa tahu kalau seseorang mulai kena HIV kalau kita sendiri gak tahu gejalanya. Jangan jangan saya bisa ketakutan kalau saya meriang abis kontak sama dia (pasien)" (K5)
}

\section{Pengetahuan dan keterampilan tentang universal precaution}

Satu hal yang hampir sama dipersepsikan responden keluarga pasien yang juga dipersepsikan oleh responden perawat adalah kebutuhan akan pengetahuan dan keterampilan keluarga dalam mencegah terjadinya penularan.

"Saya terus terang enggak tahu gimana \& apa yang harus saya lakukan, memang ada yang lain ya?......... saya lihat ibunya pasen sebelah pake sarung tangan..... saya gak tahu saya baru dateng ......." (K2)

Pengetahuan dan keterampilan yang dibutuhkan oleh keluarga seperti yang disampaikan responden $\mathrm{K} 4$ lebih pada pengetahuan dan keterampilan pencegahan penularan yang aplikatif sesuai dengan setting rumah tangga. 
"Kemaren anak saya muntah darah (hemoptisis red.) saya bersiin pake baju kotor anak saya...... Sebelum perawatnya dateng. Abis kasian anak saya....takut nungguin perawatnya lama..... bener gak sih suster? Entar kalo di rumah kayak gitu lagi gimana?" (K4)

\section{Pengetahuan dan keterampilan tentang symptom management}

Responden keluarga pasien memberi perhatian khusus pada bagaimana mereka mampu merawat pasien selama pasien berada di rumah. Seperti yang dipersepsikan responden $\mathrm{K} 1$, pengetahuan dan keterampilan yang dibutuhkan untuk symptom management adalah pada gejala sedang seperti hipertermia, batuk, penurunan nafsu makan dan menangani nyeri.

Alhamdulillah badannya udah mendingan, tadi panas banget...... saya Cuma ngebayangin nanti kalau udah di rumah gimana ya kalau panas lagi mesti diapain...? Trus kalo obat penurun panasnya abis, atau obat lainnya abis gimana ya...... (K1)

Aduh kesian adik saya...., batuk-batuk terus... kalau udah batuk sampe lemes badannya. Biasanya abis itu gak mau makan, gak tau kenapa apa kecapean atau apa. Katanya mulutnya gak enak. (K3)

Kalau udah kesakitan, Astagfirullah...... Ampuni hambaMu Ya Allah......(menangis....) saya gak kuat...... Kayaknya gak kebayang kalau kejadiannya dirumah. Di rumah gak ada siapa2 kalau semua udah pada kerja, sekolah.......(K5)

\section{PEMBAHASAN}

Persepsi tentang pengetahuan dan keterampilan yang dibutuhkan perawat dan pasien terlihat ada sedikit persamaan. Kesamaannya adalah pengetahuan dan keterampilan tentang universal precaution dan penanganan symptom management. Persamaan persepsi ini mungkin dipengaruhi pengalaman responden baik perawat maupun keluarga pasien dalam merawat pasien HIV/AIDS.

\section{Kebutuhan akan Universal Precaution dan Symptom Management}

Persamaan persepsi pada kebutuhan perawat \& keluarga akan kebutuhan pengetahuan dan keterampilan tentang universal precaution dan symptom management dimungkinkan terjadi akibat pengalaman yang mengharuskan mereka melakukan pemberian bantuan atau perawatan pada pasien HIV/ AIDS. Baik perawat maupun anggota keluarga pasien dengan HIV/AIDS yang merawat pasien mempersepsikan bahwa mereka belum cukup mampu melakukan perawatan tersebut khususnya yang berhubungan dengan universal precaution (pencegahan penularan) dan symptom management (penanganan keluhan sesuai dengan gejala yang muncul).

Pada keluarga pasien persepsi di atas dimungkinkan terjadi akibat pengetahuan yang belum memadai tentang penyakit HIV/AIDS, gejala dan manifestasi klinisnya. Hal ini memungkinkan keluarga tidak tahu tentang bagaimana cara pencegahan penularan yang tepat, termasuk juga persepsi mereka tentang ketidaktahuan akan cara penanganan keluhan/ gejala yang muncul. Kondisi ini dimungkinkan terjadi karena mereka belum mendapatkan pelatihan khusus tentang kedua hal tersebut dan karena perawat mengalami kesulitan saat harus mengimplementasikan hal tersebut. Di Amerika, perawat-perawat yang telah mendapatkan informasi tentang bagaimana melakukan universal precaution mengalami sedikit kesulitan untuk mengimplementasikan pemberlakuan peraturan universal precaution bagi semua dari badan pengawasan keselamatan kerja di Negara tersebut (Ramsey et. all, 1996).

Idealnya tindakan universal precaution merupakan bagian dari asuhan yang diberikan perawat, sehingga kualitas asuhan keperawatannya menjadi lebih baik. Kemampuan perawat untuk memberikan asuhan keperawatan sendiri, sangat dipengaruhi oleh pengetahuan dan keterampilan yang dimiliki oleh perawat tersebut, walaupun sebenarnya pengetahuan bukan satu-satunya aspek yang mempengaruhi kemampuan perawat memberikan asuhan (Waluyo, 2004).

Tindakan keperawatan symptom management yang diimplementasikan pada pasien HIV/AIDS adalah tindakan keperawatan paliatif yang juga diberikan pada pasien terminal yang lain (Newshan,1999). Dia menemukan kondisi bahwa kemampuan perawat dalam symptom management dapat diberikan pada perawat-perawat yang bekerja di ruang perawatan pasien terminal. Karena RS tempat dilakukannya penelitian ini adalah terutama untuk 
kasus terminal, pelatihan symptom management dapat diberikan untuk semua perawat. Namun kadangkala persepsi perawat yang belum yakin akan pengetahuan dan keterampilannya tentang universal precaution dan symptom management disebabkan faktor penguatan pengetahuan dan keterampilan yang dimiliki oleh perawat yang bersangkutan. Misalnya penguatan melalui acara pembahasan kasus, ronde keperawatan, dan pemilihan perawat teladan.

Di negara-negara miskin seperti di Afrika, pengetahuan yang dimiliki oleh perawat tidak hanya pengetahuan dengan kondisi serba kecukupan di mana dana tidak menjadi masalah, namun juga pengetahuan di mana perawat dapat memodifikasi keadaan sehingga asuhan perawatan yangn diberikan pada pasien HIV/AIDS tersebut mendekati seperti apa yang mereka ketahui dan pelajari. Hal ini juga di tularkan pada keluarga yang memang ikut serta secara aktif dalam proses perawatan pasien di rumah sakit (Nurseweek, 2001)

\section{Kebutuhan Keluarga Pasien akan Pengetahuan HIV/AIDS, Tanda dan Gejala serta Cara Penularannya}

Persepsi keluarga pasien yang membutuhkan pengetahuan HIV/AIDS, tanda dan gejala serta cara penularannya dimungkinkan terjadi akibat keluarga belum mendapatkan informasi spesifik tentang hal tersebut. Hal ini dapat saja terjadi pada tiap individu yang memang belum pernah mendapatkan atau terpapar informasi HIV/AIDS.

Kondisi di atas juga terjadi pada saat Waluyo (2004) melakukan penelitian untuk mengetahui pengetahuan pasien dan keluarga tentang HIV/ AIDS. Dari penelitian tersebut didapatkan bahwa pengetahuan dan keterampilan pasien dan keluarga tentang HIV rendah. Hal ini mungkin terjadi akibat sebagian pasien dan keluarga tidak mendapatkan pengetahuan dan penjelasan yang memadai dari tim kesehatan terutama dokter yang merawat.

Pengetahuan HIV/AIDS, tanda dan gejala serta cara penularannya sangat penting diketahui oleh keluarga pasien dalam membekali mereka dengan pengetahuan dasar yang bermanfaat dalam merawat anggota keluarga mereka, serta meminimalkan penularan dan penyebaran stigma dilingkungan penderita HIV/AIDS.

\section{Kebutuhan Perawat akan Pengetahuan dan Keterampilan tentang Konseling, ARV, Dukungan Mental, dan Penanganan jika Terpapar HIV}

Kemampuan perawat memberikan konseling atau berfungsi sebagai konselor harus dipersiapkan dan dilatih secara khusus karena kemampuan ini tidak didapatkan saat perawat mengikuti program pendidikan keperawatannya dahulu. Pengetahuan dan keterampilan yang dimiliki oleh perawat tentang konseling tersebut memungkinkan terjadinya peningkatan persentase jumlah pasien yang mengikuti program Anti Retro Viral (ARV) (Cristiana, 2003). Di samping itu dari penelitian yang dilakukan oleh Kamb M.L. dan kawan-kawan (1998) kemampuan konseling dari tenaga kesehatan dapat menurunkan angka risiko penyebaran HIV dan penyakit seksual menular. Sehingga kemampuan konseling sangat diperlukan oleh perawat untuk memberikan dampak positif bagi pasien dan lingkungannya.

Di rumah sakit tempat penelitian ini dilakukan, memiliki program pelatihan konseling yang diberikan pada beberapa perawat yang berhubungan langsung dengan pasien HIV terutama mereka yang mencari pelayanan konseling. Namun perawat yang memiliki kemampuan konseling ini terbatas jumlahnya, sehingga wajar apabila ada perawat yang menyampaikan bahwa mereka membutuhkan pelatihan konseling. Setelah pasien menjalani proses konseling dan kemudian secara sadar memilih untuk mengikuti pengobatan ARV, maka asuhan keperawatan yang harus dilakukan adalah untuk memastikan klien secara disiplin dapat mengkonsumsi ARV sesuai dengan program medis dan klien dapat mengantisipasi efek samping yang mungkin akan terjadi dan kalau memungkinkan menangani efek samping yang muncul sebagai akibat terapi ARV tersebut. Oleh sebab itu, sebagian perawat berpersepsi bahwa pengetahuan dan keterampilan dalam intervensi kolaboratif ARV menjadi sangat penting untuk diketahui dan dikuasai. 
Pengetahuan dan keterampilan yang dimiliki oleh perawat tentang program ARV memungkinkan peningkatan persentase angka kepatuhan pasien HIV/AIDS dalam pengobatan, peningkatan persentase jumlah pasien yang mengalami penurunan angka viral load menjadi $<400$ dan peningkatan persentase pasien yang memiliki peningkatan angka CD (CD4) > 200 (Cristiana, 2003). Seth, Jacqueline \& Demetria (2005) juga menyatakan bahwa pengobatan ARV pada individu dengan latar belakang pendidikan rendah dan pengetahuan tentang HIV dan pengobatan ARV yang rendah akan menghasilkan efektifitas pengobatan ARV yang rendah pula.

Selain efek samping ARV, pasien sebenarnya memiliki masalah lain yang cukup serius yaitu masalah infeksi oportunistik. Kedua masalah tersebut memiliki efek fisik dan psikologis yang cukup serius pada pasien yang mengalaminya. Upaya perawat dalam masalah fisik adalah melakukan asuhan keperawatan symptom management sedangkan dalam masalah psikologis perawat dapat memberikan dukungan mental. Hal ini diperkuat oleh Fried dan kawan-kawan (1996) yang menyatakan dalam penelitiannya bahwa dukungan sosial sangat diperlukan oleh pasien HIV.

Satu hal yang cukup menarik untuk didiskusikan adalah persepsi perawat yang membutuhkan pengetahuan dan keterampilan penanganan jika seseorang terpapar virus HIV. Hampir 100\% kasus terpapar virus HIV yang pernah terjadi adalah kasus kecelakaan atau ketidaksengajaan akibat kesalahan yang dilakukannya sendiri. Akibat dari kelalaian ini perawat berisiko tinggi tertular HIV. Untuk dapat meminimalkan risiko tersebut POKDISUS HIV/AIDS RSCM telah memiliki standar penatalaksanaan jika seseorang mengalami terpapar HIV (Djauzi, 2003).

Gerberding (2003) menguraikan bahwa individu yang berisiko tinggi terpapar HIV akibat kecelakaan kerja tertusuk jarum atau lainnya dapat menjalani proses penatalaksanaan individu terpapar HIV. Salah satu bentuk penatalaksanaannya adalah dengan memberikan ARV profilaksis selama 6 bulan, di samping pemantauan klien selama dan setelah masa penatalaksanaan. Standar penatalaksanaan ini dapat diimplementasikan di mana pun termasuk di tempat penelitian. Oleh karena itu sebagian perawat mempersepsikan bahwa mereka perlu mengetahui standar penanganan atau penatalaksanaan apabila seseorang terpapar HIV. Hal ini dapat meminimalkan perasaan was-was perawat.

\section{KESIMPULAN}

Perawat dan keluarga pasien mempersepsikan dirinya membutuhkan pengetahuan dan keterampilan tertentu untuk dapat secara optimal merawat pasien ketika pasien berada di rumah sakit dan di rumah. Ada persamaan persepsi antara perawat dan keluarga pasien di mana mereka sama-sama membutuhkan pengetahuan dan keterampilan tentang universal precaution dan symptom management.

Hal lain yang teridentifikasi dari perawat adalah bahwa mereka membutuhkan pengetahuan dan keterampilan tentang konseling, ARV, dukungan mental, dan penanganan jika terpapar HIV. Kebutuhan ini dirasakan oleh perawat dimungkinkan terjadi akibat permasalahan yang muncul seputar area tersebut. Sehingga akan sangat positif bagi perawat maupun pasiennya apabila perawatnya diberikan penambahan kompetensi atau keahlian tersebut.

Anggota keluarga merasakan ada dua hal lain yang oleh mereka dirasakan sebagai suatu kebutuhan adalah pengetahuan tentang apa HIV/AIDS beserta cara penularannya dan tanda dan gejala dari HIV/ AIDS. Hal ini terjadi lebih mungkin disebabkan masih terbatasnya informasi seputar HIV/AIDS dan cara pencegahannya yang ada di masyarakat. Apabila kebutuhan perawat dan keluarga pasien tersebut dapat dipenuhi, sangat mungkin angka kegagalan dalam proses terapi dan perawatan pasien HIV/AIDS akan menurun $(\mathrm{HH})$.

\footnotetext{
* Agung Waluyo, S.Kp, M.Sc. : Staf Akademik Keperawatan Medikal Bedah, FIK-UI

** Lestari Sukmarini, S.Kp. : Staf Akademik Keperawatan Medikal Bedah, FIK-UI

*** Ns. Rosakawati, S.Kep. : Peneliti RSK Dharmais, Jakarta
} 


\section{KEPUSTAKAAN}

Bennett, F.J. (1987). AIDS as a social phenomenon. Social Science and Medicine, 25, 529-539.

Cristiana. (2003). Caring for HIVAIDS patients at Christiana Care.IHI: Dealware

Culbert, G., \& Waluyo, A. (2003). Persepsi mahasiswa S1 keperawatan terhadap HIV/AIDS \& pasien $H I V / A I D S$. Laporan hasil penelitian telah dipresentasikan melalui poster pada konferensi internasional keperawatan HIV-AIDS di Chiang Mai, 7-9 Juli 2004.

DepKes. (2005). Laporan tahunan kasus HIV/AIDS. Jakarta: DEPKES

Djauzi, S., Djoerban, Z. (2003). Penatalaksanaan infeksi HIV di pelayanan kesehatan dasar. Jakarta: FKUI

Friedland, J., Renwick, R., \& McColl, M. (1996). AIDS care. Coping \& social support as determinants quality of life in HIV/AIDS. 8: 1, 15-32

Gerberding, J.L. (2003). Occupational exposure to HIV in health care setting. The New England journal of medicine.348, 826-833.

Holloway, I., \& Wheeler, S. (1996). Qualitative research for nurses. London: Blackwell Science

Holzemer. (2001).Changing face of AIDS. Philadelphia: Nurseweek

Kamb, M.L., et all (1998). JAMA. Efficacy of risk-reduction counseling to prevent human immunodeficiency virus and sexually transmitted diseases: A randomized controlled trial. Project RESPECT Study Group. 7;280(13):1161-7.
Leininger, M. (1985). Qualitative research methods in nursing. New York: Grune \& Stratton.

Merton, R.K., \& King, R. (1990). The focused interview: A manual of problems and procedures. ( $\left.2^{\text {nd }} \mathrm{ed}\right)$. New York: Free Press

Newshan, G., Sherman, D.W. (1999). Nursing Clinic North America. Palliative care: Pain and symptom management in persons with HIV/AIDS. 34(1):131-45

Nurseweek. (2001). News feature on AIDS. September: 01-09

Pelita Ilmu. (2003). Majalah Yayasan Pelita Ilmu. April: 23, 24-25

Polit, D.F., \& Hungler, B.P. (1999). Nursing Research: principle \& methods. Philadelphia: Lippincott

Ramsey, Priscilla W., C.S.; McConnell, Peggy; Palmer, Betsy H.; Lee Glenn, L. (1996). Clinical Nurse Specialist. Nurses' Compliance with Universal Precautions before and after Implementation of OSHA Regulations. 10(5):234-239

Stephenson, N., \& Corben, V. (1997). Research mindedness for practice, an interactive approach for nursing and health care. London: Churchill Livingstone

Thomas, B.S. (1990). Nursing research, an experiential approach. St. Louis: Mosby Company.

Waluyo A., Nurachmah E., Rosakawati, (2004). Persepsi pasien dan keluarga tentang HIV/AIDS dan stigma masyarakat terhadap pasien HIVI AIDS. Laporan hasil penelitian belum dipublikasikan

WHO. (2004). AIDS epidemic update. Geneva: UNAIDS 